\title{
KULTURA TERAPEUTYCZNA I KOMUNIKACJA MEDIALNA
}

\author{
Dariusz Wadowski \\ Katolicki Uniwersytet Lubelski Jana Pawła II, Wydział Nauk Społecznych \\ Instytut Dziennikarstwa i Komunikacji Społecznej \\ ORCID: https://orcid.org/0000-0001-8936-9557 \\ e-mail: darwad.kul.pl
}

\begin{abstract}
Streszczenie: Artykuł podejmuje problem terapeutycznego trendu we współczesnej kulturze, którego znaczenie wciąż rośnie, zwłaszcza ze względu na jego obecność w komunikacji medialnej i rolę mediów w upowszechnianiu jego komponentów. W artykule omówiono główne stanowiska interpretacyjne $\mathrm{w}$ ujmowaniu kultury terapeutycznej, przedstawiono jej podstawowe składniki oraz dokonano przeglądu wybranych form jej obecności w komunikacji medialnej. Stwierdzono, że właściwie w każdym aspekcie i różnych wytworach medialnej komunikacji możliwe jest dostrzeżenie terapeutycznych odniesień i wartości.
\end{abstract}

Słowa kluczowe: kultura terapeutyczna, etos terapeutyczny, język terapeutyczny, komunikacja medialna

\section{WPROWADZENIE}

Kultura terapeutyczna jest tematem, który w ostatnich kilkudziesięciu latach szczególnie intensywnie przyciąga uwagę badaczy z różnych obszarów nauk społecznych i nauk o kulturze. Konstatują oni funkcjonowanie w wysoko rozwiniętych społeczeństwach Zachodu nowego zjawiska, acz o XIX-wiecznych korzeniach, które z racji rosnącego znaczenia domaga się intensywnych badań. Systematycznej naukowej refleksji podejmowane jest ono od lat 50. i 60. XX wieku, kiedy to dostrzeżono wzrost wagi indywidualnych emocji i aktywności psychoterapeutycznej nie tylko w regulowaniu międzyludzkich stosunków, ale w szerszych obszarach kultury i życia społecznego. Trend terapeutyczny nie jest oczywiście jedynym wyznaczającym kierunki rozwoju współczesnej kultury, jednak rosnąca jego ekspansja i wpływ na wiele dziedzin życia społecznego przyczynia się do uznawania go za charakterystykę kluczową dla ponowoczesności. 
Wciąż jednak obszar znaczeniowy pojęcia kultury terapeutycznej nie jest precyzyjnie określony, ale najczęściej obejmuje się nim różnego rodzaju społeczno-polityczne implikacje rosnącej dominacji psychologii i psychoanalizy we współczesnych społeczeństwach Zachodu, która powoduje przenikanie stylów myślenia, postrzegania i opisywania rzeczywistości z obszaru samej terapii do innych dziedzin życia. Coraz częściej dostrzega się, iż elementy zaliczane do kultury terapeutycznej zajmują strategiczne miejsca w uniwersach ideologiczno-symbolicznych współczesnych społeczeństw, są masowo internalizowane przez ich członków i stosowane w konkretnych sytuacjach życiowych. Kultura terapeutyczna uważana jest więc za istotny przejaw niektórych cech funkcjonalnych współczesnego społeczeństwa, jego przekształceń społeczno-politycznych, specyficznych sposobów pojmowania znaczenia jednostki i wspólnoty, upowszechnianych kodów semiotycznych i systemów wiedzy. Staje się kluczowym źródłem kategorii i reguł organizujących społeczne struktury, instytucje, stosunki międzyludzkie i postawy względem samych siebie, częściowo wypierając dotychczasowe zasady politycznego liberalizmu i ekonomicznej efektywności. Kultura ta tworzy coś w rodzaju ogólnej matrycy, instytucjonalnie uprawomocnionej, wykorzystywanej przez współczesnego człowieka do rozumienia i kształtowania indywidualnej i społecznej tożsamości oraz budowania relacji z innymi ludźmi. Częściami składowymi tej matrycy są powiązane ze sobą dynamicznymi związkami określone wartości, ideały, symbole, wzory zachowań, precedensowe opowieści, scenariusze, kryteria oceniania, ramy wyjaśniające, binarne opozycje, kody semiotyczne, metafory itd. [Illouz 2008]. Matryca ta, podobnie jak systemy religijne, dostarcza instrumentów do całościowego rozumienia środowiska społecznego i naturalnego. Nie funkcjonuje w izolacji względem innych obszarów życia społecznego, ale łączy się z przekształceniami w sferze politycznej i ekonomicznej, w obszarze kultury medialnej i trendach oświatowych, medycynie i ideologiach. Ponieważ przyczynia się do zmiany znaczenia dotychczas obowiązujących zasad i kryteriów społecznej strukturyzacji i hierarchizacji (klasa, etniczność, płeć, wyznanie), sprzyja przekształceniom całościowej kultury w kierunku apolityczności, sekularności, kosmopolityczności [Furedi 2004].

Wśród zjawisk opisywanych zbiorczym pojęciem „kultura terapeutyczna”, to, co tradycyjnie jest związane z leczeniem i terapią, jest tylko pewnym fragmentem, częścią znacznie szerszej przestrzeni. W obrębie pola semantycznego tego pojęcia akcentuje się przede wszystkim społeczno-polityczne implikacje psychologii i psychoanalizy, mniejszą uwagę poświęca się natomiast analizie typowych praktyk terapeutycznych.

\section{UJĘCIA KULTURY TERAPEUTYCZNEJ}

W ciągu kilkudziesięciu lat refleksji nad kulturą terapeutyczną ukształtowały się dwa główne sposoby jej pojmowania - krytyczny i niekrytyczny. 
Krytyczny nurt jej rozumienia został już zarysowany w pierwszym poważnym opracowaniu dotyczącym tego przedmiotu, a mianowicie w książce Philipa Rieffa The Triumph of the Therapeutic: Uses of Faith After Freud [1966/1987]. Rieff zauważył, iż wzrost znaczenia psychologii i psychoanalizy w powojennym społeczeństwie amerykańskim wywołuje swoisty proces psychologizacji całego życia [Madsen, Brinkmann 2011; Madsen 2014] i wiąże się z przekształceniami fundamentalnych zasad rządzących życiem społecznym w kierunku indywidualizacji i prymatu jednostki nad wspólnotą. Jego zdaniem psychologia i praktyki terapeutyczne zajmują miejsce opuszczone przez religię, a psychologowie i terapeuci stają się współczesnymi kapłanami. T.J. Jackson Lears [1983], również zajmujący stanowisko krytyczne i podobnie postrzegający osłabienie znaczenia religii i moralności jako systemów dostarczających fundamentalnych reguł życiowych, podkreślał natomiast związek kultury terapeutycznej z konsumeryzmem. Uważał, że protestancki etos zbawienia przez wiarę jest zastępowany wiarą w samozbawienie dzięki samorealizacji oraz obsesyjną koncentracją na własnym samopoczuciu psychicznym. Etos terapeutyczny traktował jako rodzaj współczesnej hegemonii kulturowej. Głośna krytyka Christophera Lascha natomiast wychodziła od punktu skupiania się młodych ludzi na przekształcaniu własnego wnętrza, zamiast na usiłowaniach zmiany społecznej. Lasch uważał, że kultura terapeutyczna definiuje całościowy klimat kultury, wypiera nie tylko religię i moralność, ale również politykę. „Terapia ustanowiła siebie jako spadkobierczynię zarówno twardego indywidualizmu, jak i religii, ale to nie oznacza, że »zwycięstwo terapii« stało się nową religią samą w sobie. Terapia ustanawia antyreligię, nie zawsze pewną, ponieważ odnosi się do racjonalnego wyjaśniania lub naukowych metod uzdrawiania, jakie jej wyznawcy będą nam chcieli wmówić" [Lasch 2015: 39]. Indywidualizm charakterystyczny dla współczesnej kultury stał się natomiast przedmiotem krytyki podjętej przez Franka Furediego [2004]. Zauważył on, że „fiksacja na Ja” prowadzi do dezorganizacji sfery publicznej i dewaluacji życia prywatnego, a związana z kulturą terapeutyczną popularność wszelkiego rodzaju wyznań przyczynia się do powstawania swego rodzaju kultu ofiary.

Drugi nurt krytyki kultury terapeutycznej jest związany z koncepcjami dyskursu i dyscypliny zaproponowanymi przez Michela Foucault [2018]. Twierdził on, że dyskurs rozwijany przez kulturę terapeutyczną jest nową formą nadzoru i zarządzania liberalnym społeczeństwem. W procesach wyłaniania się współczesnej formy Ja dostrzegł znaczenie dyskursu naukowego, a zwłaszcza pochodzącego z obszaru nauk psychologicznych (tzw. psy-discuorse). Zdaniem Foucault, przenikający do różnych sfer życia język psychologiczny oraz wzrost znaczenia psychologii w zarządzaniu jest $w$ gruncie rzeczy nową formą sprawowania ideologicznej władzy.

W krytycznych analizach kultury terapeutycznej zauważalna jest skłonność nie tylko wiązania jej z kryzysami kulturowymi współczesnych społeczeństw, sfery publicznej, społecznego Ja, autorytetów moralnych i religijnych, ale wręcz do obwiniania etosu terapeutycznego za owe kryzysy. 
Wśród analiz kultury terapeutycznej o charakterze niekrytycznym do najbardziej wpływowych należy koncepcja Anthony'ego Giddensa [2002]. Dostrzegł on w rozwoju kultury terapeutycznej przede wszystkim przejaw dążeń refleksyjnych jednostek do zapanowania nad własnym życiem. Według Giddensa etosu terapeutycznego nie należy traktować wyłącznie jako sekularnego substytutu czy repliki dawnego autorytetu religijnego, nie wiąże się on z upadkiem wszelkich autorytetów moralnych i nie jest objawem masowego rozchwiania osobowości. Giddens zaliczył terapię do całego i wewnętrznie zróżnicowanego zespołu systemów eksperckich istotnych zwłaszcza dla warstw uprzywilejowanych. Potraktował ją jako „metodologię planowania życia”, ułatwiającą jednostkom samorozumienie, harmonizowanie aktualnych doświadczeń z doświadczeniami przeszłymi oraz projektami przyszłościowymi. Jest ona wyrazem „uogólnionej refleksyjności, w pełni daje wyraz zaburzeniom i wątpliwościom, które niesie nowoczesność. Jednocześnie stanowi część typowej dla porządku późnej nowoczesności mieszaniny szans i ryzyka" [Giddens 2002: 246]. Korzystanie z zasobów kultury terapeutycznej nie oznacza więc podporządkowania się narzuconej dyscyplinie, ale otwiera możliwości sprawowania kontroli nad życiem. Jest to szczególnie istotne na przykład w kontekście wzrastającej roli związków o charakterze „,czystej relacji”, w sytuacji „zapośredniczenia i separacji doświadczenia”, gdzie kultura terapeutyczna dostarcza skutecznych instrumentów samorozumienia i integracji tożsamości. Giddens dostrzegł zarazem pewne niebezpieczeństwa związane z całkowitym podporządkowaniem się wymogom kultury terapeutycznej, ale - jego zdaniem - stanowią one po prostu jedno $\mathrm{z}$ wielu ryzyk, z jakimi późnonowoczesny człowiek musi sobie radzić.

Bardziej pozytywne postrzeganie znaczenia kultury terapeutycznej występuje również w analizach wiążących ją z kwestią płci, a zwłaszcza rolą i pozycją kobiet, odczuwanymi przez nie emocjami oraz instytucjonalnym i eksperckim wsparciem służącym rozwiązywaniu ich problemów [Wright 2008].

\section{KOMPONENTY KULTURY TERAPEUTYCZNEJ}

Kultura terapeutyczna jest zjawiskiem złożonym, dynamicznym, ujawniającym się w poszczególnych obszarach z różnym nasileniem i na różne sposoby. Wśród podstawowych jej komponentów lub płaszczyzn występowania można wyróżnić cztery, wzajemnie ze sobą powiązane, acz wewnętrznie niejednorodne:

1) etos terapeutyczny, czyli zespół wartości i kryteriów oceniania, norm, reguł i wzorów zachowań;

2) zasoby symboliczne, w skład których wchodzi słownictwo i reguły jego używania, kody semiotyczne, metafory, symbole i mity;

3) baza instytucjonalna, którą stanowią zarówno sformalizowane formy działań terapeutycznych (kliniki, poradnictwo, kursy, szkolenia, warsztaty), jak i niesformalizowane, obecne w popularnych mediach i wydawnictwach poradnikowych; 
4) komponent behawioralny obejmujący zachowania werbalne i pozawerbalne podejmowane wobec siebie $\mathrm{i}$ innych.

Wewnętrzne skomplikowanie i wielowymiarowość kultury terapeutycznej nie pozwala na szczegółowe omówienie powyższych komponentów, z tego powodu zwrócimy tylko uwagę na kilka wybranych kwestii. Jedną z nich są okoliczności decydujące o wkraczaniu kultury terapeutycznej w dziedziny i obszary dotąd od niej odległe, gdzie jej obecność była uważana do niedawna nie tylko za nieprawdopodobną, ale wręcz nieuprawnioną.

Eva Illouz [2008: 20] mówiła o trzech podstawowych uwarunkowaniach rozwoju kultury terapeutycznej i rosnącego jej znaczenia.

Po pierwsze, ten typ kultury wydaje się być dobrze dopasowany do sposobu doświadczania przez współczesnego człowieka zmian w strukturze społecznej, w której pewne role, pozycje i hierarchie ulegają przewartościowaniu i transformacji, pojawiają się nowe napięcia i konflikty, zasady podziałów i kryteria autorytetu.

Po drugie, kultura terapeutyczna dostarcza skutecznych instrukcji postępowania w typowych sytuacjach niepewności lub w obszarach, nad którymi człowiekowi trudno jest zapanować, o dużym potencjale konfliktogennym (seksualność, rasa, miłość, bogactwo itp.).

Po trzecie, charakteryzuje się znacznym stopniem instytucjonalizacji, zyskuje uznanie i wsparcie społecznych elit, jej składniki krążą w obrębie formalnych i nieformalnych sieci społecznych.

Dzięki tym warunkom kultura terapeutyczna rzeczywiście działa, a ludzie wierzą $\mathrm{w}$ jej zbawienne skutki, ponieważ potrafią połączyć jej ofertę ze swoim życiem i doświadczeniem.

Ekspansja tendencji terapeutycznych w kulturze owocuje ukształtowaniem się czegoś w rodzaju „emocjonalnego stylu” pozwalającego wiązać różnorodne elementy otaczającego świata z własnymi przeżyciami. Styl ten jest widoczny w różnych segmentach życia społecznego: w funkcjonowaniu wielkich korporacji, szkołach, rodzinie, małżeństwie, grupach rówieśniczych. Jednym z jego skutków są przekształcenia relacji między płciami. Mężczyźni, na wzór kobiet, są zachęcani do większej wrażliwości, troskliwości, negocjowania, a przede wszystkim do rozwijania umiejętności empatii i mówienia o własnych uczuciach. Służy do tego specjalny ,język emocjonalny” dostarczający niezbędnego słownictwa, definicji pojęć oraz skojarzonych z nimi znaczeń. Język ten jest wykorzystywany jako narzędzie introspekcji i rozumienia samego siebie, służy także pomocą $\mathrm{w}$ ustalaniu kierunków własnego rozwoju i prezentowania siebie innym. Zwrotnie generuje specyficzne emocjonalne praktyki, określa sposoby postrzegania problemów wewnętrznych oraz problemów w otaczającym świecie, ustala ich hierarchię i kształtuje nastawienia do nich. Pierwotnie rozwijany przez profesjonalnych psychologów i terapeutów przenika do sfery potoczności, gdzie jest wykorzystywany do opisywania tego, co wiąże się na przykład z intymnymi przeżyciami, relacjami międzypłciowymi, seksualnością, przywództwem, pod- 
miotowością, sprawczością, podporządkowaniem, dysfunkcjami, chorobami itp. Staje się składnikiem standardowych kompetencji komunikacyjnych, z którymi łączą się wymagania umiejętności mówienia o własnych emocjach i przeżyciach, stresie, lęku, niepokojach, samopoczuciu, traumie.

Występowanie wspomnianego stylu emocjonalnego nie jest ograniczone do jakiejś jednej sfery życia społecznego, związanej wyłącznie z profesjonalną terapią. Staje się on coraz ważniejszy w edukacji, gdzie kładzie się nacisk na społeczne umiejętności, wrażliwość, uzależnienia, empatię, tolerancję, zrozumienie, poczucie wartości. Nauczanie tego stylu odbywa się nie tylko w standardowej praktyce edukacyjnej, ale organizowane są specjalne warsztaty, szkolenia, kursy, skierowane również do ludzi dorosłych, które dostarczają możliwości jego poznania i uczą praktycznego wykorzystywania [Brunila 2012]. Styl ten nabiera coraz większego znaczenia w polityce i komunikowaniu politycznym, gdzie zajmuje miejsce racjonalnej argumentacji [Richards 2004; Keller, Kleinen-von Königslöw 2018] ${ }^{1}$. Ważna jest też jego rola w gospodarce i nowoczesnych strategiach menedżerskich kładących nacisk na elastyczność, dostosowanie, adaptacyjność, zarządzanie karierą, uczenie się przez całe życie, kompetencje komunikacyjne itp. [Apperley, Jacobs, Jones 2014: 728]. Dostrzegalne są także jego funkcje w obszarze twórczości artystycznej, w tym literackiej [Szurman, Woźniakowska, Kowalczyk-Twarowski 2015].

Barry Richards i Joanne Brown stwierdzili, że powyższy styl emocjonalny $\mathrm{i}$ terapeutyczny trend w kulturze obejmują trzy podstawowe składniki: emocjonalną ekspresywność, refleksyjność i postawę empatii (współczucia) [Richard, Brown 2011: 20]. Elementy te $\mathrm{z}$ jednej strony opisują wymagania, jakie stawia współczesna kultura, a z drugiej wskazują, za pomocą jakich środków się ona wyraża. Wiąże się ona z pewną formą wyobraźni emocjonalnej, umiejętnościami empatii, sposobami myślenia o sobie i relacjach z innymi, o dobrym (właściwym, szczęśliwym) życiu, a także dostarcza określonych środków i instrukcji ich stosowania w codziennych sytuacjach. W jej obrębie dokonuje się legitymizacja zachowań i działań związanych z publiczną ekspresją emocji, cierpień i niepokojów wynikających ze społecznych napięć i konfliktów [Wright 2008: 333].

\section{ZNACZENIE MEDIÓW W ROZWOJU KULTURY TERAPEUTYCZNEJ}

Nie sposób rozważać terapeutycznej tendencji w kulturze w oderwaniu od problematyki mediów, gdyż to media właśnie odpowiadają za dużą część działań upowszechniających elementy kultury terapeutycznej. Z pewnością trudno byłoby obarczać je wyłączną odpowiedzialnością i przypisywać rolę sprawczą,

1 Jako paradygmatyczny przypadek uprawnionej obecności tego stylu w polityce często wskazuje się aferę seksualną prezydenta Clintona wraz z jego późniejszymi wyznaniami i thumaczeniami. 
traktując jako jedyną przyczynę procesów emocjonalizacji i psychologizacji życia. Jak się jednak wydaje, odgrywają one kluczową rolę we włączaniu tendencji terapeutycznych w główny nurt praktyk kulturowych i ich uprawomocnianiu. Różnego rodzaju medialne przekazy uczą, jak w zwykłych i rutynowych działaniach dostrzegać i doceniać wartość terapeutyczną, w jaki sposób jej poszukiwać w aktywnościach związanych z pracą, wypoczynkiem, czasem wolnym, prowadzeniem gospodarstwa domowego, życiem towarzyskim i uczestniczeniem w kulturalnych imprezach. Współczesne media, zwłaszcza technologie cyfrowe, pozwalają użytkownikom nie tylko na odbieranie obrazów, tekstów, opowieści, symboli i metafor, ale także na ich aktywne tworzenie i przekształcanie oraz dzielenie się nimi.

Przejawów kultury terapeutycznej można poszukiwać w wielu konkretnych wytworach działalności medialnej, zarówno w ich treściach, jak i rozwiązaniach formalnych. Intensywność i zakres tej obecności jest jednak mocno zróżnicowany w zależności od rodzaju mediów, form przekazu i gatunków, a praktyczne ich oddziaływanie jest uzależnione od sposobów korzystania z mediów i kompetencji medialnych odbiorców.

Treści przekazów medialnych dotyczą właściwie wszystkich problemów nurtujących współczesnego człowieka i wymiarów jego życia wewnętrznego. Media ukazują i tłumaczą skomplikowane sytuacje i problemy życia wewnętrznego, podejmują zagadnienia, takie jak poczucie wartości, komfort psychiczny, alienacja, przynależność, zaangażowanie, samoocena, satysfakcja, zazdrość, niepokój, uzależnienie, gniew itp. Można powiedzieć, że znajduje się w nich całe spektrum treściowe tego, co łączymy z pojęciem kultury terapeutycznej.

Stosunkowo najłatwiej jest ono dostrzegalne w różnego rodzaju formach fabularnych (filmach i serialach), umożliwiających opowiadanie o wspomnianych problemach przez pryzmat losów jednostkowych bohaterów. W niektórych przypadkach stanowią one kanwę orientującą akcję całego utworu filmowo-telewizyjnego (np. Rodzina Soprano, Dr House, filmy Woody'ego Allena).

Richards i Brown [2011: 22] zauważyli, że wkomponowane w treść filmów i seriali elementy kultury terapeutycznej stanowią jeden z najważniejszych czynników jej upowszechniania. Film stawia przed oczyma widzów te problemy, które są wypierane i w codziennych trudach zapominane, przypomina o ich istnieniu, zachęca do ich przemyślenia, a także dostarcza instrukcji możliwych rozwiązań. Sprzyja więc podejmowaniu refleksji nad własnym życiem, analizowaniu własnych emocji, dylematów wewnętrznych, wątpliwości oraz możliwych rozwiązań w kontekście ekranowych perypetii bohaterów. Filmowe przekazy nie pełnią w ścisłym znaczeniu funkcji terapeutycznych, ale zachęcają do pewnych aktywności psychicznych i zewnętrznych, które bez tego bodźca nie zostałyby podjęte.

Równie znaczącym kanałem propagowania kultury terapeutycznej są programy typu reality show i talk show. $Z$ dużym prawdopodobieństwem można nawet powiedzieć, że etos terapeutyczny i język emocji występują w tego typu gatunkach intensywniej niż w pozostałych. Wydawcy programów, za pomocą od- 
powiednich środków przedstawiania, starają się te emocje przybliżyć odbiorcom, niekiedy nawet specjalnie aranżując wydarzenia, aby sprowokować bohaterów do wybuchów emocji. Ekspresja skrajnych emocji przed kamerą jest tu stale dopuszczalna, w niektórych przypadkach wręcz pożądana. Jednym z gatunkowych wyznaczników tych programów jest obecność wyznań podejmowanych zarówno przez zwykłych ludzi, jak i celebrytów [White 2002]. W wyznaniach mają być obecne „prawdziwe emocje”, przy czym ich autentyczność jest związana ze szczegółowością i stopniem intymności [Aslama, Pantii 2006]. Ważne jest tutaj dowartościowanie ,prawdy pierwszej osoby” związane z wymogiem, aby osobiście czegoś doświadczyć, a następnie w umiejętny sposób o tym doświadczeniu zakomunikować [Brenton, Cohen 2004: 32-35]. Programy typu talk show mają tworzyć namiastkę rozmowy w kręgu przyjaciól, w których uczestnicy udzielają sobie nawzajem wsparcia i pomocy oraz okazują zrozumienie [Aslama, Pantii 2006: 180]. Janice Peck zauważyła, że w programach typu talk show dochodzi do transformacji społecznych konfliktów w problemy psychologiczne, sprowadzenia ich do psychologicznych, jednostkowych dysfunkcji, które mogą się stać zadaniami do rozwiązania i podlegać działaniom terapeutycznym [Peck 1995].

W tym samym nurcie gatunkowym medialnej twórczości, gdzie obecne są elementy kultury terapeutycznej, znajdują się programy koncentrujące się wokół tematu transformacji: zmiany wyglądu, relacji, nastawienia do rzeczywistości, ukształtowania nowego Ja. Należą tu na przykład programy typu medical show, podczas których dochodzi do ujawnienia różnego rodzaju niedostatków fizycznych i wynikających stąd cierpień psychicznych, a na wizji podejmowane są działania terapeutyczne [Abramowicz 2014]. W produkcjach tego typu przemiany zostają dowartościowane, ukazane jako sposób rozwiązywania wielu problemów, często mają one natychmiastowe skutki, a sam przebieg procesu przemiany jest szczegółowo prezentowany. Jest to część tendencji nazwanej przez Małgorzatę Bogunię-Kozłowską „,kulturą metamorfoz” [Bogunia-Kozłowska 2012].

Zastanawiając się nad terapeutycznym oddziaływaniem programów tego nurtu, Richards i Brown (2011) zauważyli, że zachodzi tutaj swoisty proces medialnej „normalizacji” cierpień wewnętrznych, dysfunkcji, chorób, niedostatków; ukazywane są one jako typowe, całkowicie „normalne”, a więc wymagające raczej empatii, troski i wsparcia, aniżeli ukrywania i piętnowania. Niektórzy badacze mediów zwrócili jednak uwagę, że szeroka i przyjmująca wiele postaci obecność elementów kultury terapeutycznej w takich produkcjach medialnych nie pociąga za sobą zainicjowania rzeczywistej relacji terapeutycznej ani nie realizuje funkcji terapeutycznych. Motywacje uczestników programów typu talk show i reality show niekoniecznie dotyczą bowiem zrozumienia czy wsparcia, bardziej chodzi tu po prostu o możliwość zaistnienia w przestrzeni medialnej [Ptaszek 2007: 93]. Warto również zwrócić uwagę, że większość programów mieszczących się w kategoriach gatunkowych reality show, talk show, medical show jest produkowanych na podstawie formatów globalnych. Fakt ten oznacza, że elementów kultury terapeutycznej ujawniających się w tych programach nie 
sposób przyporządkowywać do konkretnego kręgu kulturowego, a przekraczający granice państw i społeczeństw obieg medialnych treści sprawia, że stają się one jednym z przejawów globalizującej się kultury [Mellucci 1996]. Bywają one określane zbiorczym mianem emotainment, a wśród podstawowych cech tego gatunku wymienia się m.in. personalizację, prymat osoby i jej przeżyć nad faktami i ogólnym obrazem, dążenie do autentyczności przez ,prawdziwe historie" i ,prawdziwe emocje”, wywoływanie wrażenia intymności za pomocą wyznań dotyczących prywatności, posługiwanie się językiem zrozumienia, empatii i wsparcia [Wetschanow 1999].

Dużą część powyższych spostrzeżeń można również zastosować w odniesieniu do tzw. telewizji śniadaniowej, gdzie często podejmowane są problemy zdrowia i komfortu psychicznego, relacji międzyludzkich, samorozwoju i zarządzania własnym życiem. Nie brakuje tam porad i wskazówek udzielanych przez profesjonalnych i nieprofesjonalnych ekspertów, wyznań celebrytów i ,zwykłych ludzi”, dzielących się swymi doświadczeniami i prezentujących swoją postawę wrażliwości i troski [Bogunia-Borowska 2009; Dąbrowska-Cendrowska 2011]. Język emocji jest tu traktowany jako uprawniony sposób wypowiedzi uczestników (również dziennikarzy), którzy za jego pomocą opowiadają o swoim medialnym i pozamedialnym życiu. Eksponowanie wyznań o sukcesie i jego kosztach, hedonizmie, chorobach, anoreksji, depresji, zdradach, nienawiści fanów, odrzuceniu, niestabilności emocjonalnej, nałogach, kryzysach itp., mimo że wzbudza wśród odbiorców skrajnie różne postawy, zachęca też do współczucia i rozwijania postawy wrażliwości. Przez historie konkretnych ludzi ukazujące pewne sposoby rozwiązywania swoich problemów odbiorcy mogą dopasowywać te problemy i wzorce ich rozwiązywania do swojej codzienności.

Interesującym zagadnieniem w tym kontekście są interakcje między kulturą terapeutyczną a medialną kulturą celebrytów. Podkreśla się często, że celebryci stanowią kategorię o szczególnym nasileniu problemów tożsamościowych, szczególnie głębokich kryzysach tożsamości i intensywnych działaniach zorientowanych na jej budowanie i przekształcanie zgodnie $\mathrm{z}$ antycypowanymi żądaniami publiczności. Jak wykazała Aneta Ostaszewska w swym studium o Michaelu Jacksonie [2009], jego emocjonalne i tożsamościowe perypetie w komentarzach medialnych i internetowych powszechnie były interpretowane za pomocą kategorii zaczerpniętych z dyskursu terapeutycznego.

Innym przykładem obecności elementów kultury terapeutycznej w mediach są przekazy reklamowe. Reklama ujawnia skrywane w zwykłym życiu pragnienia, pożądania i fantazje, wskazuje źródła satysfakcji i konsekwencje niezaspokojenia, informuje o potencjalnych obiektach dążeń. Terapia oferowana przez reklamę znacznie wykracza poza porządek rynku i zwykłą aktywność zakupową, jest ona wpisana w sam proces obcowania z reklamą [Richards, Brown 2002: 25-27]. W wielu przypadkach samo obcowanie z reklamą, jej odbiór uruchamiający marzenia o lepszym życiu, dobrym samopoczuciu i szczęściu już może pełnić funkcje terapeutyczne. 
Od wpływów kultury terapeutycznej nie jest wolne także dziennikarstwo informacyjne. Dziennikarze newsowi i komentatorzy spraw bieżących nie tylko je relacjonują i opisują, ale sięgając po język emocji, kształtują postawy niechęci lub współczucia, zwracają uwagę na winę i wstyd, kładą nacisk na autentyczność, formułują oceny, dzielą się z odbiorcami swoimi sposobami doświadczania świata, bardziej lub mniej otwarcie mówią o swoich rozczarowaniach, rozterkach, wątpliwościach. Kompetencje zarządzania emocjami coraz częściej wchodzą w zakres ogólnych kompetencji dziennikarskich, wymaganych zwłaszcza podczas relacjonowania sytuacji kryzysowych, katastrof, zamachów terrorystycznych i innych traumatycznych wydarzeń [Richards, Rees 2011]. Warto w tym miejscu zauważyć, że w programach informacyjnych towarzyszących takim wydarzeniom zazwyczaj pojawiają się eksperci z zakresu psychologii, na bieżąco udzielając porad dla widzów, w jaki sposób radzić sobie z trudnymi sytuacjami. Bywają oni również proszeni o dokonywanie znacznie dalej idących diagnoz i interpretacji, wyjaśnienie przyczyn i długofalowych konsekwencji wydarzeń, a w takich wypadkach wychodzą poza swą standardową rolę i jeszcze inaczej przyczyniają się do upowszechniania się kultury terapeutycznej.

Prócz wspomnianych programów telewizyjnych jako przykład wpływów kultury terapeutycznej trzeba wspomnieć jeszcze o dynamicznie rozwijającym się przemyśle poradnikowym [Olchanowski, Sieradzan 2011]. Ważną rolę w propagowaniu terapeutycznego etosu odgrywają magazyny dla kobiet, często współpracujące z ekspertami z zakresu psychologii i rozwoju osobistego. Porady dotyczące zarządzania własnym życiem, odczuwania i wyrażania emocji, korzystania z języka terapeutycznego oraz postrzegania swojej indywidualności stanowią jedną z ich podstawowych treści [Madsen, Ytre-Arne 2012].

Współegzystujące w przestrzeni medialnej języki emocji i terapii obejmują zarówno wiedzę formalną, jak i nieformalną, tę, która pochodzi zarówno ze źródeł uznanych i posiadających autorytet, jak i takich, które są anonimowe, o wątpliwych podstawach autorytetu. Te drugie istnieją przede wszystkim dzięki sieci internetu, gdzie użytkownicy kierując się własnymi przekonaniami, udzielają sobie porad, dzielą się jednostkowymi doświadczeniami, wspierają się nawzajem, dyskutują i wypracowują rozwiązania problemów itd. Intensywnie rozwija się także e-terapia, teleterapia, cyberporadnictwo skoncentrowane głównie na problemach zdrowia i komfortu psychicznego. Autorka wpisu na jednym z portali tego typu wyjaśnia: „Należy pamiętać, by terapii online nie utożsamiać z psychoterapią, gdyż nigdy nie zastąpi ona terapii tradycyjnej. Pod wieloma względami e-terapia podobna jest do życiowego coachingu (life-coaching). Chociaż terapeuci online nie mogą diagnozować ani leczyć chorób psychicznych w Internecie, mogą oferować porady osobom doświadczającym problemów w związkach, pracy lub życiu" [Cherry 2018]. Wprawdzie internetowi terapeuci dostrzegają pewne ograniczenia w swej działalności, to niekoniecznie są one równie istotne dla zwykłych użytkowników, zwłaszcza znajdujących się w trudnych sytuacjach życiowych. Portale, fora dyskusyjne, blogi, profile społecznościowe obrazują proces 
demokratyzacji dyskursu terapeutycznego oraz przenikania go do różnych sfer codzienności. Posługiwanie się językiem terapeutycznym, formułowanie sądów i wskazywanie sposobów rozwiązania problemów nie jest tutaj zarezerwowane wyłącznie dla profesjonalnych psychologów i psychoterapeutów, ale może być realizowane właściwie przez każdego.

\section{KONKLUZJE}

Przywołane tutaj przykłady nie wyczerpują oczywiście całego repertuaru środków i kanałów, za pomocą których są upowszechniane komponenty kultury terapeutycznej. Tendencje terapeutyczne są identyfikowane w wielu obszarach całościowej kultury, jako jedna z jej głównych właściwości. Kultura terapeutyczna nie funkcjonuje w izolacji w stosunku do profesjonalnej terapii i związanych z nią instytucji leczenia i wsparcia. Korzysta z wypracowanych w nich wybranych metod i strategii rozwiązywania problemów, posługuje się niektórymi elementami języka psychologii i psychoterapii, ale na swój sposób je przeformułowuje i upraszcza, tak aby były dostępne dla wszystkich. Proces ten dokonuje się przede wszystkim dzięki mediom, zarówno tym tradycyjnym, które wypracowały specyficzne „terapeutyczne" formaty i gatunki, jak i dzięki nowym mediom stwarzającym niezwykle dynamiczną, wielowymiarową i zróżnicowaną przestrzeń cyrkulacji jej elementów. Użytkownicy mediów stają się aktywnymi uczestnikami kultury terapeutycznej, wprowadzając te składniki do swoich planów egzystencjalnych i projektów tożsamościowych, traktując je jako wyznaczniki właściwego sposobu życia.

\section{Title: Therapeutic Culture and Media Communication}

Summary: The article addresses the problem of a therapeutic trend in contemporary culture, which is still growing, especially due to its presence in media communication and the role of the media in the dissemination of its components. The article discusses the main interpretative positions in the recognition of therapeutic culture, presents its basic components and reviews selected forms of its presence in media communication. It has been found that in almost every aspect of media communication and in various products of media it is possible to see therapeutic references and values.

Keywords: therapeutic culture, therapeutic ethos, therapeutic language, media communication

\section{BIBLIOGRAFIA}

1. Abramowicz B. (2014), Wszystko na wierzchu, czyli o fenomenie „prawdy na ekranie”. Uwagi na marginesie programu Sekrety chirurgii, „Teraźniejszość - Człowiek - Edukacja”, nr 65 (1), s. $38-56$.

2. Apperley A., Jacobs S., Jones M. (2014), Introduction: Therapeutic Culture, "Culture Unbound", vol. 6, s. 725-729. DOI: https://doi.org/10.3384/cu.2000.1525.146725. 
3. Aslama M., Pantti M. (2006), Talking Alone. Reality TV, Emotions and Authenticity, "European Journal of Cultural Studies", vol. 9 (2), s. 167-184. DOI: https://doi. org/10.1177/1367549406063162.

4. Bogunia-Borowska M. (2012), Fenomen telewizji. Interpretacje socjologiczne i kulturowe, Wydawnictwo Uniwersytetu Jagiellońskiego, Kraków.

5. Bogunia-Borowska M. (2009), Telewizja śniadaniowa, czyli codzienność z telewizja na żywo, [w:] Barwy codzienności. Analiza socjologiczna, red. B. Bogunia-Borowska, Warszawa.

6. Brenton S., Cohen R. (2004), Polowanie na ludzi. Za kulisami reality TV, Wydawnictwo Muza, Warszawa.

7. Cherry K. (2018), What You Need to Know About Online Therapy A Look at the Ins and Outs of Online Psychotherapy, https://www.verywellmind.com/what-is-online-therapy-2795752 [dostęp: 25.10.2018].

8. Dąbrowska-Cendrowska O. (2011), Telewizja śniadaniowa. Celebryci, porady i audioteleprzynęty na kobieca publiczność?, „Media i Społeczeństwo”, nr 1, s. 29-39.

9. Foucault M. (2018), Rzadzenie soba i innymi. Wykłady z Collège de France 1982-1983, Wydawnictwo Naukowe PWN, Warszawa.

10. Furedi F. (2004), Therapy Culture: Cultivating Vulnerability in an Uncertain Age, Routledge/ Tylor and Francis Group, New York, NY.

11. Giddens A. (2002), Nowoczesność i tożsamość. ,Ja” i społeczeństwo w epoce późnej nowoczesności, Wydawnictwo Naukowe PWN, Warszawa.

12. Illouz E. (2008), Saving the modern soul: Therapy, emotions, and the culture of self-help. University of California Press, Berkeley.

13. Keller T., Kleinen-von Königslöw K. (2018), Pseudo-discursive, mobilizing, emotional, and entertaining: identifying four successful communication styles of political actors on social media during the 2015 Swiss national elections, "Journal of Information Technology \& Politics", s. 1-20. DOI: 10.1080/19331681.2018.1510355.

14. Lasch Ch. (2015), Kultura narcyzmu. Amerykańskie życie w czasach malejących oczekiwań, Wydawnictwo Akademickie Sedno, Warszawa.

15. Lears T.J.J. (1983), From Salvation to Self-realization. Advertising and the Therapeutic Roots of the Consumer Culture, 1880-1930, [w:] The Culture of Consumption: Critical Essays in American History 1880-1980, Pantheon Books, New York, NY, s. 1-38.

16. Madsen O.J., Ytre-Arne B. (2012), Me at My Best: Therapeutic Ideals in Norwegian Women's Magazines, "Communication, Culture and Critique", vol. 5 (1), s. 20-37. DOI: https://doi org/10.1111/j.1753-9137.2011.01118.x.

17. Madsen O.J. (2014), Psychologisation and Critique in Modern-day Western Culture, "Social and Personality Psychology Compass", nr 8/5, s. 193-200, DOI: 10.1111/spc3.12103.

18. Madsen O.J., Brinkmann S. (2011), The Disappearance of Psychologisation?, “Annual Review of Critical Psychology”, nr 8, s. 179-199, https://thediscourseunit.files.wordpress.com/2016/05/ arcp8madsenbrinkmann.pdf.

19. Mellucci A. (1996), Challenging Codes: Collective Action in the Information Age, Cambridge University Press, Cambridge.

20. Olchanowski T., Sieradzan J. (2011), Wprowadzenie do problematyki narcyzmu. Od klasycznych koncepcji narcyzmu do narcyzmu kultury zachodniej, [w:] Narcyzm, red. J. Sieradzan, Wydawnictwo Uniwersytetu w Białymstoku, Białystok.

21. Ostaszewska A. (2009), Michael Jackson jako bohater mityczny. Perspektywa antropologiczna, Wydawnictwa Akademickie i Profesjonalne, Warszawa. 
22. Peck J. (1995), TV Talk Shows as Therapeutic Discourse: the Ideological Labor of the Talking Cure, "Communication Theory", vol. 5 (1), s. 58-81. DOI: https://doi.org/10.1111/j.1468-2885.1995. tb00098.x.

23. Ptaszek G. (2007), Talk show. Szczerość na ekranie?, Wydawnictwa Akademickie i Profesjonalne, Warszawa.

24. Richards B. (2004), The Emotional Deficit in Political Communication, "Political Communication", nr 21 (3), s. 339-352. DOI: 10.1080/10584600490481451.

25. Richards B., Brown J. (2011), Media as Drivers of the Therapeutic Trend?, "Free Associations: Psychoanalysis and Culture, Media, Groups, Politics", No. 62, s. 18-30.

26. Richards B., Rees G. (2011), The management of emotion in British journalism, "Media, Culture \& Society”, nr 33 (6), s. 851-867. DOI: 10.1177/0163443711411005.

27. Rieff Ph. (1987), The Triumph of the Therapeutic: Uses of Faith after Freud (with a new preface), University of Chicago Press, Chicago.

28. Szurman J., Woźniakowska A., Kowalczyk-Twarowski K. (red.), (2015), The Self Industry Therapy and Fiction, Wydawnictwo Uniwersytetu Śląskiego, Katowice.

29. Wetschanow K. (1999), “The Personal Is Political”-Are Daytime Talk Shows Feminist?, [w:] A Decade of Transformation, IWM Junior Visiting Fellows Conferences, Vol. 8: Vienna, s. 1-19, http://www.iwm.at/wp-content/uploads/jc-08-101.pdf.

30. White M. (2002), Television, Therapy, and the Social Subject; or, The TV Therapy Machine, [w:] Reality Squared. Televisual Discourse on the Real, Rutgers University Press, New Brunswick, NJ, s. 313-321.

31. Wright K. (2008), Theorizing Therapeutic Culture. Past influences, future directions, "Journal of Sociology", vol. 44 (4), s. 321-336. DOI: 10.1177/1440783308097124. 